\title{
DESIGN, CZYLI O DEFORMUJACYM FORMOWANIU I INNYCH PARADOKSACH PROJEKTOWANIA
}

\section{On deforming forming and other design paradoxes}

\begin{abstract}
This paper joins the philosophical reflection on design. A historiosophical approach to this phenomenon is complemented by phenomenological descriptions depicting different types of its paradox. Design is considered here as an effect of the impetus for visualization encoded in Western culture and connected with the privileged position of the sense of sight present in this culture. The visibility of things - products - is to restore in modern people a sense of security and to deliver them from the fear of nothingness. Such a historiosophical approach is connected to constructivism, as it combines design with the creation of reality, the creation which consists in imposing form - i.e. human program and project - on (chaotic) things. Main theorem: Thing-form-shaping practices are not neutral with respect to existence and axiology because they also inevitably de-form the world. Questions: What does this paradox mean and in what ways does it emerge, and how is it given in experience? What is the end of all these experiments (with regard to appearances, shapes and forms) conducted on reality or nature? What are the cultural, moral, political or social consequences of reducing the meaning - and existence - of things to their visible shapes?
\end{abstract}

Keywords: design, design paradoxes, design as a pharmacon, modern existence, visibility, capitalism, consumption, nihilism

\section{Wprowadzenie}

Design to słowo klucz do świata współczesnej kultury - mody, architektury, materiałów, produkcji przemysłowej i użytkowej, coraz liczniejszych wokół nas, projektowanych komputerowo towarów, przedmiotów i obrazów medialnych. Proponuję spojrzeć na projektowanie jako na efekt znacznie szerszego zjawiska, jakim jest zakodowany w kulturze zachodniej impuls do wizualizacji, związany z uprzy- 
wilejowaną pozycją zmysłu wzroku w dostępie do prawdziwej wiedzy o świecie. W nowoczesności stał się on czymś więcej - zaczął spełniać także funkcję instynktu samozachowawczego: widzialność miała zastąpić nam pustkę po utracie bytu, któremu sens nadawała dotąd transcendencja. Istnieć zaczęło znaczyć dla nas być postrzeganym - widzialnym. W kapitalistycznym środowisku nastawieni jesteśmy na produkcję towarów i poddani oddziaływaniu zarówno ze strony tych towarów, jak i nowych technologii, służących do ich wytwarzania. Widzialność rzeczy - produktów - ma przywrócić nam poczucie bezpieczeństwa i wyzwolić ze strachu przed nicością. Taka perspektywa historiozoficzna łączy się z podejściem konstruktywistycznym, wiąże bowiem design z tworzeniem rzeczywistości, polegającym na narzucaniu rzeczom form - naszych, ludzkich projektów i programów; na wydobywaniu na światło dzienne wszystkiego, co w tych rzeczach było dotychczas ukryte, a w czym drzemią potencje czynienia naszego życia lepszym w szerokim tego słowa znaczeniu - (bardziej) rzeczywistym, piękniejszym, bezpieczniejszym, przyjemniejszym, pożyteczniejszym. Ale te rzeczo-formo-twórcze praktyki nie są bynajmniej neutralne, ani egzystencjalnie, ani aksjologicznie, ponieważ nieuchronnie również świat de-formuja. Co ten paradoks oznacza, w jaki sposób się przejawia i jak dany jest nam w doświadczeniu? Czym kończą się eksperymenty z „rzeczywistością” lub „naturą”, której narzuca się obce jej wyglądy, kształty lub formy? Jakie są kulturowe, moralne, polityczne i społeczne skutki zredukowania znaczenia - i istnienia - rzeczy do ich widzialnych kształtów? Pytania te stanowią oś przewodnią poniższych rozważań.

\section{Design i nowoczesność}

Design w industrialnej nowoczesności był synonimem tego, co „nowoczesne”. Zainteresowanie projektowaniem narzędzi i maszyn pokrywa się z początkiem rewolucji przemysłowej. Pierwsze towarzystwo wzornictwa przemysłowego powstało w Szwecji w 1849 roku - następne pojawiły się wkrótce potem kolejno w Austrii, Niemczech, Danii, Anglii, Norwegii i Finlandii. „Projektantów tego okresu - jak pisze Victor Papanek - interesowało nadawanie formy, poszukiwanie stosownego piękna w narzędziach mechanicznych i maszynowo wykonywanych przedmiotach. Kiedy patrzyli na maszynę, widzieli w niej rzecz nową, która domaga się - jak sądzili - dekoracyjnych upiększeń". Produkowane maszynowo towary z biegiem czasu miały być już nie tylko piękne w swej formie - wedle obowiązujących w danym kraju kanonów estetycznych - lecz także funkcjonalne i pożyteczne, zdolne poprawić i ułatwić warunki życia ludzi w nowoczesnym, dynamicznie zmieniającym się świecie. W 1915 roku brytyjscy designerzy, biznesmeni i przedsiębiorcy założyli w Londynie stowarzyszenie charytatywne The Design \& Industries Association (DIA), pod hasłami „Fitness for Purpose” (Przydatność do celu [wzgl. do potrzeb])

\footnotetext{
V. Papanek, Dizajn dla realnego świata. Środowisko człowieka i zmiana społeczna, przeł. J. Holzman, Recto Verso, Łódź 2012, s. 46.
} 
oraz „Nothing Need Be Ugly” (Nic nie musi być brzydkie)2. Stowarzyszenie miało zmienić sposoby projektowania i postrzegania towarów przez publiczność, uświadomić jej rolę, jaką design dóbr i usług może odegrać w polepszeniu jakości życia zbiorowości i jednostek. Idee $\mathrm{z}$ ducha oświeceniowe, emancypacyjne - zaprawione brytyjskim utylitaryzmem i empiryzmem. „The Times” pisał wówczas o tym przedsięwzięciu: „Całkowicie praktyczne, ani trochę artystyczne”, a literacki magazyn „Athenaeum”: „Z zadowoleniem witamy DIA z uwagi na jego zdrowy rozsądek oraz obszar działań”, i optymistycznie dodawał: „to właśnie ten duch współpracy w kierunku wspólnego celu, który stanie się zbawieniem nie tylko dla naszego systemu gospodarczego, lecz także całego naszego narodowego życia"’.

Kiedy prawie sto lat temu, w 1920 roku, stowarzyszenie to zorganizowało w Londynie wystawę pod tytułem Przedmioty domowe (Household Things), przeznaczoną szczególnie dla publiczności z klasy robotniczej, to w katalogu do niej tak tłumaczyło między innymi brak ornamentów i niepotrzebnych zakrzywień w sztućcach produkowanych wówczas w Niemczech: „Przedstawiamy to publiczności po to, by zobaczyła, że od artykułów codziennego użytku wymaga się, by były one proste, przydatne do wykorzystania i zachwycające w swej koncepcji. W tym sensie będą dodatkiem stworzonym dla radości życia"4. To główny zamysł przyświecający nowoczesnemu projektowaniu przemysłowemu i użytkowemu - utożsamiony z ideą postępu, napędzał on gospodarkę i życie społeczne do czasu, kiedy w światowej opinii publicznej świadomość negatywnych skutków tych praktyk (niektórych z nich) zaczęła brać górę nad pozytywnymi. Wraz z rozwojem społeczeństwa dobrobytu i konsumpcji nowoczesny, emancypacyjny zamysł projektowania okazał się przeciwskuteczny design zamiast uprzyjemniać, ułatwiać i upiększać życie w epoce postindustrialnej, zaczął je komplikować i mu zagrażać, pociągając za sobą wiele problemów, takich jak zatrucie środowiska, ocieplenie klimatu, wyczerpywanie się nieodnawialnych zasobów surowców naturalnych, źródeł wody pitnej itd. Masowa produkcja i konsumpcja, zdawać by się mogło, osiągnęły apogeum. Społeczeństwo industrialne w drugiej połowie XX wieku w rezultacie zaczęło zamieniać się w postindustrialne, w którym sektory administracji i usług dominowały nad produkcją, a wiedza i informacja stawały się ważniejsze od wydobycia węgla i rud żelaza.

Rzecz paradoksalna, że w tych nowych warunkach rozwiązywanie wspomnianych problemów, dziedziczonych po twardej, industrialnej nowoczesności, również nie jest możliwe bez udziału designu - takiego jednakowoż, od którego oczekuje

2 Zob. stronę domową tej organizacji: http://www.dia.org.uk/. Na temat „fitness for purpose” zob. M.T. Saler, The Avant-Garde in Interwar England: Medieval Modernism and the London Underground, Oxford University Press, Oxford 1999, s. 73-74.

3 Cyt. za: DIA Nothing Need Be Ugly Chapter 1 - Official Support and Initial Successes, http://www. dia.org.uk/page/aboutus/nothing_Need_be_Ugly/DIA_Nothing_Need_be_Ugly_Chapter_1_-_Official_Support_and_Initial_Successes (dostęp: 5.06.2019).

4 Cyt. za: A. Powers, Bauhaus Goes West: Modern Art and Design in Britain and America, Thames \& Hudson Ltd., London 2019, s. 23-24. 
się wyjścia poza kwestie natury estetycznej oraz zmiany zastanych systemów wartości, postaw i zachowań. Ale przecież, jak widzieliśmy, dokładnie tego samego oczekiwali także od swojej publiczności pionierzy projektowania już sto lat temu. Czyżby więc sama ta praktyka kulturowa nie była obciążona wewnętrzną sprzecznością, a w niej samej nie była zaprojektowana jakaś opcja samozniszczenia? Fatum, ironia losu, która w samym sercu nowoczesności implantuje farmakon. Dziwne lekarstwo, uzdrawiające i jednocześnie pogłębiające chorobę, przeciw której pierwotnie powstało. Co to takiego?

\section{Design, przypadek i horror vacui}

Słowo „design”, jak w jednym ze swoich mistrzowskich esejów przypomina Vilém Flusser $^{5}$, oznacza nie tylko plan, projekt, ale także spisek, nikczemny cel. Dlaczego te negatywne konotacje obok neutralnych znaczeń planowania i projektowania? Odpowiedź na to pytanie nieuchronnie, nomen omen, jest także rodzajem szczególnego projektu badawczego, przeprowadzonego z wykorzystaniem metody analizy fenomenologicznej oraz semantycznej i etymologicznej. Zacznę od fenomenologicznego oglądu zjawiska projektowania. Oto jego ogólny opis, jaki zaproponował Papanek - praktyk i teoretyk designu:

Każdy człowiek jest projektantem. Wszystko, co prawie cały czas robimy, ma związek z projektowaniem, ponieważ odgrywa ono zasadniczą rolę we wszelkich ludzkich działaniach. Procesem projektowym jest planowanie i kształtowanie przebiegu wykonywania dowolnej czynności z myślą o realizacji pożądanego, przewidywalnego celu. Gdybyśmy próbowali wydzielić projektowanie jako rzecz samą w sobie, postępowalibyśmy wbrew oczywistym faktom, ponieważ stanowi ono podstawowy, elementarny składnik egzystencji. [...] Przesuwanie monet po blacie to jakby czynność projektancka w miniaturze. Jako działalność służąca rozwiązywaniu problemów - projektowanie nie może z definicji prowadzić do jednej słusznej odpowiedzi. Mniej lub bardziej słusznych odpowiedzi jest zawsze nieskończenie wiele. Słuszność dowolnego rozwiązania projektowego będzie zależała od znaczeń, jakie nadamy układowi ${ }^{6}$.

Z tego opisu wynika, że projektowanie powiązane jest z rozwiązywaniem problemów - wszelkich, również tych, na które natrafiamy w codzienności. Co więcej, ich rozwiązywanie ma dokonywać się wedle metody, która nie prowadzi do zero-jedynkowych rozstrzygnięć. Gdyby w oglądzie i opisie tej sytuacji sięgnąć do klasycznej typologii rozumowań, to trzeba by stwierdzić - najpierw negatywnie - że przy projektowaniu nie mamy więc do czynienia z rozumowaniem typu apodyktycznego, czyli polegającym na wyprowadzaniu wniosku w drodze sylogizmu z bezspornych przesłanek. Nie wiąże się więc z ,rzeczywistym dowodzeniem” dążącym

V. Flusser, O terminie „, design”, przeł. P. Wiatr, „Kultura Współczesna” 2016, nr 4.

V. Papanek, op. cit., s. 23, 25.

Arystoteles, Retoryka, w: idem, Retoryka. Poetyka, przeł. H. Podbielski, PWN, Warszawa 1988, s. 67. 
do prawdy - jedynie prawdziwego, adekwatnego rozwiązania. Nie sposób też przypuszczać - to dalsza część negatywnego (czym ono nie jest) określania zjawiska za pomocą terminologii Arystotelesowskiej - że projektowanie polega na rozumowaniu typu dialektycznego. To ostatnie wychodzi bowiem z przesłanek prawdopodobnych, z których możliwe są co najmniej dwa poprawne wnioski - wybiera się lepszy do przyjęcia. Jeśli wartościowania „lepszy” lub „słuszniejszy” odnoszą się do celu, któremu ma służyć projekt, i wiążą się ze sposobem osiągania tegoż celu, czyli z funkcją, którą ma spełniać projektowany przedmiot, to te przymiotniki muszą stosować się do znacznie większej liczby nadających się do przyjęcia wariantów niż tylko do dwóch. Do nieskończenie wielu nie tylko mniej lub bardziej, lecz także tak samo dobrych bądź słusznych rozwiązań, przez co należałoby rozumieć „pięknych”, „poręcznych”, ,atrakcyjnych” itd. Każde z tych określeń jest wieloznaczne - każde jest słowną formą ekspresji, która wyraża naszą reakcję na to, co ma dla nas znaczenie, co w określony sposób rozumiemy. Znaczenie nie jest zatem czymś gotowym, obecnym w rzeczach. Ma naturę relacyjną i negocjacyjną - jest produktem naszego myślenia i mówienia o nich, formułowania na ich temat sądów w interakcji z innymi ludźmi, w których polu zainteresowań mieszczą się odnośne rzeczy. To, co nowożytni - za Immanuelem Kantem - nazywają władzą sądzenia, starożytni łączyli z rozumem jako fronesis, mądrością praktyczną, ona zaś zwykle oparta jest na wywodach o charakterze retorycznym, żeby raz jeszcze nawiązać do typologii Arystotelesa ${ }^{8}$. W ramach tej klasycznej siatki pojęciowej trzeba by więc projektowanie przypisać rozumowaniu retorycznemu, nastawionemu na perswazję, przekonanie, emocjonalne przyciągnięcie do słuszności proponowanego rozwiązania danego problemu. Ten sposób myślenia i komunikowania dominuje w naszej codzienności, co pozwala nam twierdzić - za Papankiem - że każdy z nas jest projektantem oraz że (właśnie dlatego) istnieje też nieskończenie wiele równie słusznych rozwiązań praktyczno-technicznych problemów, z którymi na co dzień się borykamy. Ich prawdziwość, w sensie zgodności z pewnym zastanym, „naturalnym”, transcendentnym stanem rzeczy, nie ma tu znaczenia.

Ale to nie wszystko w sprawie projektowania. Na dodatkowy trop jego rozumienia naprowadza nas etymologia słowa design. Nie powołują się na nią wprawdzie miarodajne słowniki języków nowożytnych, takich wydawców jak na przykład u nas PWN, w Niemczech Duden czy Oxford w Wielkiej Brytanii. Wszystkie zgodnie ograniczają się jedynie do semantyki, wiążąc design z kształtowaniem rzeczy użytkowych, nadawaniem im formy, projektowaniem ich ${ }^{9}$. Etymologia nieco kom-

Ibidem, s. 69.

9 Duden traktuje Design jako jeden z synonimów Gestaltung i podaje następujące wyjaśnienie: „nadawanie kształtu pod względem formalnym i funkcjonalnym i wynikająca stąd forma przedmiotu użytkowego lub innego; szkic projektu (Entwurf[szeichnung])" (https:/www.duden.de/rechtschreibung/Design [dostęp: 6.09.2019]). Czasownik gestalten - kształtować w sensie: „1. nadawać rzeczy określoną formę, określony wygląd; 2. rozwijać się w określony sposób, stawać się" (https://www. duden.de/rechtschreibung/gestalten [dostęp: 6.09.2019]). Podobnie jest w słowniku oxfordzkim: „Plan 
plikuje to pole semantyczne. Słowo design wywodzi się od łacińskiego czasownika designo 'określać, oznaczać, pokazać', którego rdzeń to signo 'oznaczać, podpisać, położyć pieczęć'; rzeczownik signum to z kolei 'znak, pieczęć, sygnał, hasło'. Nowy element, który informacje te mogą wprowadzić do znaczenia pojęcia design, wiąże się z przedrostkiem de-. Zastosowany do tworzenia słów pochodzenia łacińskiego, przedrostek ten wprowadza znaczenie przeciwne lub negatywne, w rezultacie czego powstają opozycyjne pary pojęć, takie jak na przykład formować - deformować, aktywizować - dezaktywizować, humanizować - dehumanizować lub, tym razem $\mathrm{w}$ języku angielskim, hydrate 'nawadniać' - dehydrate 'odwadniać' itd. ${ }^{10}$ Podobnie jest z sygnowaniem, które oznacza podpisanie czegoś nazwiskiem, parafką, znakiem firmowym - zakłada się, że nazwa własna zastępuje jej nośnik, znaczące pokrywa się ze znaczonym - wszelkimi jego aktualnymi właściwościami (na tym opiera się między innymi idea copyrightu) - podczas gdy desygnowanie ma znaczenie odwrotne, wskazuje na odebranie komuś jego dotychczasowych właściwości i zlecenie mu innych - objęcia jakiejś funkcji, władzy lub stanowiska; podobnie w logice i językoznawstwie desygnat danego znaku wiąże się z oderwaniem uwagi odbiorcy od samego znaku i zwróceniem jej ku czemuś innemu - ku temu, do czego on się odnosi, co on oznacza. Wniosek: de-signo, zaprzeczenie, pozbawienie lub odwrotność znaczenia słowa signo, wskazuje na deformowanie lub fałszowanie czegoś bądź wprowadzenie w błąd, zdezorientowanie lub oszukanie kogoś lub czegoś.

Powyższy ekskurs językoznawczy tłumaczy farmakoniczne działanie designu, jego nierozerwalnie powiązane ze sobą pozytywne i negatywne konotacje znaczeniowe, o których, mniej lub bardziej boleśnie, informuje nas także doświadczenie. Projektowanie, nadawanie rzeczom, ideom lub zjawiskom formy - kształtu pod względem formalnym i funkcjonalnym - które towarzyszy naszym codziennym zmaganiom, koniecznie łączyłoby się w takim razie $\mathrm{z}$ ich deformowaniem, a na poziomie motywacji - z ukrytymi intencjami dezorientowania, manipulowania, pewną wolą przechytrzenia kogoś lub czegoś, spiskowania przeciw komuś lub czemuś. Brzmi to dość paradoksalnie, ale wystarczy chwila zastanowienia, by uświadomić sobie, że w rzeczy samej tak właśnie jest, gdy projektując na „realny świat” nasze wizje, plany i programy, za każdym razem naruszamy jakiś zastany stan rzeczy, mający znamiona „naturalności”, cokolwiek by przez to rozumieć. O kosztach, jakie musimy ponosić za swoją pychę w poskramianiu „natury”, prędzej czy później dowiadujemy się za sprawą zignorowanych bądź po prostu nieprzewidywalnych konsekwencji naszych czynów. Konsekwencje te szczególnie zaś są dotkliwe w przypadku projektowania

lub rysunek zrobiony po to, by pokazać wygląd i funkcję lub działanie budynku, ubrania lub innego przedmiotu, zanim zostanie zbudowany lub wykonany; 2. wzór dekoracyjny; 3 . cel lub planowanie, które odnosi się do działania, faktu lub przedmiotu" (https://www.lexico.com/en/definition/design [dostęp: 6.09.2019]).

10 Tę prawidłowość słowotwórczą potwierdza słownik języka polskiego, informując, że przedrostek de-, dez- to ,pierwszy człon wyrazów złożonych wskazujący na zaprzeczenie, pozbawienie lub odwrotność tego, co nazywa drugi człon złożenia” (https://sjp.pwn.pl/szukaj/de.html [dostęp: 6.09.2019]). 
- poczynając od czasów rewolucji przemysłowej - narzędzi i maszyn, których zastosowanie wpływa na wszystkie niemal sfery naszego życia: więzi społeczne, politykę, zdrowie, biosferę itd. Weźmy dla przykładu opis ,,ironii losu”, który przedstawia Papanek w związku z wynalazkiem samochodu:

Nikomu się nie śniło, że samochód, przyswojony na masową skalę, stanie się amerykańską sypialnią na kółkach i nowym miejscem kopulacji (uwolnionym od nadzoru rodziców czy współmałżonków); że przyniesie wzrost mobilności społecznej i spowoduje rozlanie się miast i obszarów podmiejskich, a w dalszej kolejności - powstanie przedmieść-sypialni; że usankcjonuje śmierć 50 tysięcy osób rocznie; że nas zbrutalizuje [...] że zaburzony zostanie rozwój społeczności, co będzie prowadziło do alienacji; że wszyscy w przedziale wieku od lat szesnastu do sześćdziesięciu będą systematycznie zastawiać swoje życie na sumę około 150 dolarów miesięcznie ${ }^{11}$.

Skąd ta krótkowzroczność wynalazców-projektantów? Spolegliwie można by powiedzieć, że bierze się ona nie tyle z ich beztroski i nieodpowiedzialności, ile z samej przygodnej natury rzeczy i spraw ludzkich. Że zatem w design nieuchronnie wpisany jest przypadek, czyli zdarzeniowy sposób istnienia, którego nie zna ani idealny świat platoński, ani nowoczesny świat abstrakcyjnych praw naukowych. Te ostatnie przypominają - i tu odwołam się do Fryderyka Nietzschego - „wielką budowlę pojęciową”, która „wykazuje sztywną regularność rzymskiego kolumbarium”, a jej logika „promieniuje rygorem i chłodem właściwym matematyce” ${ }^{2}$. To właśnie dzięki temu możemy bezbłędnie przewidywać wszystkie możliwe skutki naszych projektów, pod warunkiem że będą one stosowały się do praw tejże logiki. Coś za coś: chłód i bezbarwność pojęć i matematycznych praw w zamian za niepewność i nieprzewidywalność kolorowego i ciepłego świata, którego przewodnikiem znaczeń - nigdy dość jasnych i wyraźnych - mogą być jedynie artystyczne projekty zawarte w metaforach i plastycznych obrazach. Te ostatnie zdają się bliższe sprawom ludzkim niż nauka niestrudzenie pracująca nad owym pojęciowym kolumbarium. $\mathrm{Na}$ co dzień operujemy językiem metaforycznym, obrazowym, wieloznacznym, niedającym się ogarnać ani zdyscyplinować przez żadne rygory intelektualnej poprawności. Wedle tradycji filozoficznej język codzienności miałby być artykulacją rozumu praktycznego - podpowiadającego nam, co jest dla nas dobre - i poietycznego, nastawionego na wytworzenie czegoś, co dotąd nie istniało, i dlatego wykorzystywanego szczególnie w technice. Design wiąże się z technicznym, czyli medialnym, projektowaniem świata, przy założeniu, że media potraktujemy jako wszelkie urządzenia techniczne, narzędzia i aparaty komunikujące nas z otoczeniem - z „,naturą”, która domaga się obrobienia, nadania jej kształtu lub formy, jakiej wcześniej nie miała.

Słowo „technika” pochodzi od greckiego techné (później łac. ars 'sztuka'), które źródłowo oznacza umiejętność budowania dachów. W rzeczy samej polega ona na

11 V. Papanek, op. cit., s. 32.

12 F. Nietzsche, O prawdzie i ktamstwie w pozamoralnym sensie, w: idem, Pisma pozostałe 1862-1875, przeł. B. Baran, Inter Esse, Kraków 1993, s. 190. 
swego rodzaju oszukiwaniu natury przez cieślę (tekton) - wciskaniu przez niego bezkształtnej materii (hyle) - drewna - w zaprojektowaną formę. Gdyby spojrzeć na tę praktykę z punktu widzenia platońskiej teorii idei, to okaże się, że tego rodzaju zabiegi, zręczne sztuczki nieuchronnie zniekształcają samą rzeczywistość, czyli właśnie owe idee, oryginały zmysłowych kształtów świata. Kiedy cieśla buduje dom, to używa do tego między innymi takiego narzędzia jak dźwignia, która pozwala mu przechytrzyć prawo grawitacji. Realizuje więc swój projekt tylko za cenę zdrady, której dopuszcza się na naturze. Przechytrza naturę, wytwarzając jedynie powierzchowne jej podobieństwa. Tak oto technika ucieleśnia w sobie kluczowy mechanizm całej ludzkiej kultury - mechanizm farmakonu: obnaża jej sztuczność, uświadamia nam, że istnieje cienka linia lub chwiejna równowaga między tym, co w kulturze dobre, co pomaga nam żyć i przeżyć, a tym, co jest w niej iluzją, uwodzącą nas, odciągającą od tego, co prawdziwie dobre i piękne ${ }^{13}$. Kopię bierzemy w rezultacie za oryginał. Dwoistość - jako opozycję tego, co rzeczywiste, i tego, co fikcyjne, czyli zaplanowane i zaprojektowane - traktujemy jako harmonijną jedność. Za tym złudzeniem kryje się przekonanie o niczym nieograniczonej sile sprawczej ludzkiego projektowania. Otwarcie potwierdzają to dziś filozofowie designu:

Idea osiągnięcia czegoś 'poprzez design' sugeruje, że designerzy mają ogromną siłę. Sugeruje ona - w przeciwieństwie do determinizmu technologicznego - że ludzie mogą sterować rozwojem technologicznym. Co więcej, opiera się ona na założeniu, że w designie znaczącą rolę odgrywa intencjonalność: że przez świadome decydowanie o kierunku działania można lepiej projektować ${ }^{14}$.

Pytanie, czy istnieją jakieś granice dla tego pędu ku „lepszemu”, to znaczy ku doskonaleniu „realnego świata”? Założenie, że takich granic nie ma, to złudzenie optyczne, za które musimy płacić wielką cenę. Wiadomo, że wizja niewyobrażalnych skutków projektowania nowoczesnych narzędzi i maszyn spędzała sen z oczu wielu pokoleniom humanistów i filozofów, alergicznie reagujących na zachodni racjonalizm i jego wytwory w postaci techniki i rewolucji przemysłowej - począwszy od Marksa i Nietzschego, przez Martina Heideggera, Hannah Arendt, Edmunda Husserla, filozofów ze szkoły frankfurckiej, a skończywszy na poststrukturalistach i ich niezliczonych naśladowcach. Temat to dobrze znany - nie miejsce, żeby go tu rozwijać. Doświadczeni wojnami światowymi, totalitaryzmami i Zagładą, wykazywali oni niezbicie (przypadek Heideggera zostawiam nieco na boku), że za zatarcie różnicy między ludzkim projektem a rzeczywistością płacimy cenę znacznie większą niż ta, której żąda od nas przywołany powyżej samochód. Tym większą, im większy zostawiamy margines swobody na doskonalenie otaczającego nas świata rzeczy i ludzi, im bardziej ulegamy czarowi i perswazyjnej sile naszych projektów, im więcej

13 Zob. V. Flusser, op. cit., s. 190-194.

14 P. Feng, A. Feenberg, Thinking about Design: Critical Theory of Technology and the Design Process, w: P.E. Vermaas et al. (red.), Philosophy and Design: From Engineering to Architecture, Springer, Austin 2008, s. 106. 
więc ulegamy złudzeniu, że przekształcenia ludzi i rzeczy nie znają granic ani barier, że wszystko „w zasadzie” jest bezgranicznie plastyczne. I że wszystko też zawarte jest w widzialnych kształtach rzeczy - w nich wyczerpuje się całe ich znaczenie. Że esse est percipi - jak ujął to George Berkeley - istnieć to być postrzeganym, czytaj: widzialnym. To najgłębsze źródło dramatu nowoczesnej egzystencji. Złudzenie, które ostatecznie prowadzi do rozpaczy i szaleństwa, do strachu przed pustką - horror vacui - „zarówno wewnętrzną, jak i zewnętrzną"15.

\section{W pogoni za widzialnością}

Metafizyczny strach przed pustką napędza ludzką wyobraźnię do zapełniania jej obrazami - widzialnymi kształtami rzeczy. W kulturze zachodniej od wieków zakodowany jest dlatego imperatyw wizualizowania - przekonanie, że wszystko, co istnieje, ostatecznie ma być widzialne. Dziedzicami tej tradycji są dziś przemysł, wykorzystujący najnowsze technologie, oraz instytucje państwa i gospodarki. Wszyscy wychodzą z założenia, że żadna sfera doświadczenia nie jest sama przez się niewymierna - w każdej można znaleźć wskaźniki, to znaczy dane wymierne, i przekształcić je „do postaci wizualnej reprezentacji”'16. Wskaźniki nie muszą być koniecznie niewizualne (do nich chciałby ograniczyć zjawisko wizualizacji na przykład Lev Manovich), mogą być bowiem także wizualne - wizualizowanie danych wzrokowo postrzegalnych polegać może na zmianie ich porządku (na przykład sekwencji obrazów umieszczonych na stronie internetowej lub klatek filmowych) bądź też na ich obróbce - powiększaniu, pomniejszaniu, wyostrzaniu, redukowaniu, multiplikowaniu itd.

Wymierna, czyli znacząca, poddająca się wskaźnikowaniu, jest wszelka nasza praca i jej wytwory, środki i energia, których używamy w realizacji czegokolwiek - budowy domu, samochodu, napisaniu książki lub artykułu naukowego, produkcji kilograma wieprzowiny, operacji oka, lotu na Księżyc... Wszelkie towary i artefakty, których używamy, są - a jeżeli nie, to zmierza się do tego, że być powinny - wykonane według przyjętych (coraz częściej w skali międzynarodowej) standardów (określanych na przykład przez normy ISO lub listy referencyjne, lub bazy ewaluacyjne czasopism naukowych), zaopatrzone w wyczerpującą informację o sobie, częściowo zawartą na kodzie paskowym przeznaczonym dla czytników elektronicznych, pozwalających identyfikować produkty (ich zasoby, dysponujące nimi jednostki handlowe itd.), ale także rozmaite kupony, rachunki, przesyłki kurierskie, recepty... Pozostałe informacje znajdziemy na stronie domowej producenta w internecie. Dzisiaj potencjalnie wszystko wokół nas może więc zostać rozpoznane przez programy komputerowe: naszymi projektami są nie tylko rzeczy-artefakty, lecz także abstrakcyjne

15 V. Papanek, op. cit., s. 34. Zob. też L. Kołakowski, Odwet sacrum w kulturze świeckiej, w: idem, Czy diabeł może być zbawiony i 27 innych kazań, Aneks, Londyn 1984, s. 172.

16 L. Manovich, Czym jest wizualizacja?, przeł. M. Korzewski, w: M. Boguni-Borowska, P. Sztompka (red.), Fotospoleczeństwo. Antologia tekstów z socjologii wizualnej, Znak, Kraków 2012, s. 463. 
zjawiska (powiedzmy, takie jak jakość życia, szczęście czy wolność gospodarcza - każde z nich ma swoje wskaźniki), świat ożywiony - fauny i flory - i nieożywiony; cała materia w różnych stanach jej skupienia - ciał stałych, cieczy i gazów - może zostać chemicznie, genetycznie i biologicznie zaprojektowana, sklasyfikowana wedle przyjętej siatki wskaźników.

Zdaje się, że temu cywilizacyjnemu imperatywowi wizualizacji, który ma zapewnić ludziom poczucie bezpieczeństwa i zdjąć z nich strach przed pustką - ów horror vacui - nic nie jest w stanie się oprzeć, przynajmniej od czasów odkrycia techniki fotografii, a gdyby dalej sięgnąć, to i od siedemnastowiecznej rewolucji naukowej. Przypomnę chociażby kilka wydarzeń z tej epoki, które wpisują się w historię wizualizacji: Galileusz (1564-1642), uchodzący za ojca nowoczesnej fizyki, w 1609 roku konstruuje teleskop - instrument służący do oglądania odległych obiektów - i następnie go udoskonala. Pierwsza jego wersja daje powiększenie trzykrotne, ostatnia trzydziestokrotne. Holenderski przyrodnik Antonie Van Leeuwenhoek (1632-1723), ojciec mikrobiologii, wytwarza małe soczewki szklane o bardzo małej ogniskowej - dawały one powiększenie do 300 razy, co pozwoliło mu odkryć bakterie, obserwować czerwone krwinki i plemniki kilku gatunków zwierząt itd. Barokowi uczeni, a także artyści i poeci łączą takie właśnie zaskakujące, najbardziej różnorodne i od siebie oddalone sfery doświadczenia przez dostrzeganie i wyrażanie uniwersalnych odpowiedniości we wszechświecie ${ }^{17}$. Dzisiaj te same odpowiedniości, znacznie dokładniej rejestrowane, skanowane przez elektroniczne mikroskopy i teleskopy i następnie automatycznie analizowane, pojawiają się w obrębie obrazu utworzonego na ekranie komputera. Każdy obraz jest zapisany cyfrowo, podlega algorytmicznej obróbce: można go powiększać lub pomniejszać, usuwać z niego zakłócenia, traktować jako moduł - oddzielny element - i łączyć z innymi, tworzyć większe całości, wreszcie można też zautomatyzować te czynności za pomocą programów komputerowych - graficznych lub tekstowych ${ }^{18}$.

Imperatyw wizualizowania płynie z samego źródła zachodniej cywilizacji, opartej na idei opanowania sił przyrody i stworzenia racjonalnych form życia - idei będącej synonimem postępu cywilizacyjnego. „Wiara - jak uczy Biblia - rodzi się z tego, co się słyszy" (Rz 10,17) ${ }^{19}$, wiedza natomiast - z tego, co się widzi, jak chce nowożytna nauka. A zresztą i ona nie była w tym oryginalna, podążała bowiem za powszechnie znanymi obrazami platońskimi, przyrównującymi widzenie do słońca i używającymi metafory wzroku do wyjaśnienia ostatecznych przyczyn wiedzy i prawdy ${ }^{20}$. Stąd

17 Zob. np. S. Barańczak, Wstęp, w: Antologia angielskiej poezji metafizycznej XVII stulecia, wybór, przekł., wstęp i oprac. S. Barańczak, PIW, Warszawa 1982.

18 Zob. L. Manovich, Język nowych mediów, przeł. P. Cypryański, Wydawnictwa Akademickie i Profesjonalne, Warszawa 2006, s. 91-118.

19 Cyt. za: Biblia Tysiaclecia, Pallottinum, https://biblia.deon.pl/rozdzial.php?id=279 (dostęp: 10.09.2019).

20 Zob. Platon, Państwo, t. II, przeł. W. Witwicki, PWN, Warszawa 1991, s. 51-52 (508 B, E), 70-71 (519, B, C, D). 
i pobudzane przez nią (naukę) nieugaszone pragnienie zobaczenia wszystkiego, co (jeszcze) niewidzialne lub niedostatecznie, nie dość wyraźnie widzialne, w świetle przyjętych kryteriów/oczekiwań/możliwości technologicznych, i co za każdym razem, na każdym etapie swojej (nie)widzialności domaga się także pewnego rodzaju opowiadania w postaci teorii, wizji, koncepcji, historii, ogólnie - językowych, kulturowych reprezentacji realizowanych projektów. Poruszamy się niejako po okręgu - od abstrakcyjnego słowa do obrazu i z powrotem. Nie zachowujemy się przez to jednak od razu jak ofiary zachodniej racjonalizacji. Przyjęcie takiej perspektywy w nowożytnym projektowaniu nie oznacza deterministycznego podejścia do techniki, czyli traktowania jej jako bytu autonomicznego, z jej unikalną racjonalnością, popychającą ją (technikę) do nieustannie wzrastającej efektywności i jakoby decydującą o naszym postępowaniu. Przyznaję raczej, w duchu konstruktywizmu społecznego, że projektując, kierujemy się wyborami technologicznymi opartymi na rozważaniach uwzględniających konteksty, normy lub tożsamości kulturowe, społeczne, ekonomiczne czy polityczne. Wszyscy podlegamy też przy tym pewnej prawidłowości natury antropologicznej, zgodnie z którą intelektualnej treści (aktu) poznania nie da się odseparować od obrazowych przedstawień rzeczy, o czym nauczał już Platon. Ale to także oznacza, że nie da się myślenia oderwać od projektowania zewnętrznych kształtów rzeczy, mobilizujących rozumowanie retoryczne, nastawione na uwodzenie, oczarowanie, oszukanie... Że nie ma bezpośredniego dostępu do rzeczy, bez momentu ich kreowania, pozorowania, fałszowania... Że nie ma istnienia bez narzuconej nań obręczy projektu umysłowego, nie ma formowania bez deformowania...

\section{Cztery paradoksy projektowania}

Nowoczesny świat, postmetafizyczny, którego składniki przestały różnić się od siebie jakościowo, substancjalnie, dostępny jedynie matematykom i fizykom, utracił czar tajemnicy i stał się monotonny, płaski i bezbarwny - „sprowadzony do funkcji umysłu - jak powiada poeta - był dla zwykłego człowieka blady, nieprawdziwy i wręcz odrażający"21. Na barki tegoż zwykłego człowieka spada więc teraz odpowiedzialność za upiększenie miejsca swojego pobytu, uczynienie go bardziej ludzkim i mniej odrażającym. Jest to wyzwanie zarówno praktyczne, jak i teoretyczne - jeśli w ogóle jeszcze nadal ma sens takie rozróżnienie. Stworzyć nową metafizykę - medialną, czyli teorię bytu wymyślonego, zaprojektowanego, silnie perswazyjnego, nastawionego na wzbudzenie do niego zaufania i upodobania u jego użytkowników, przerażonych strachem przed pustką istnienia. Wielka odpowiedzialność i wielkie ryzyko. Naśladowanie Boga ze świadomością jego nieistnienia. Ten ciężar biorą na swoje barki wielcy kapitalistyczni wynalazcy w stylu Edisona, Forda czy Disneya, zastąpieni obecnie przez geniusza designu, którego archetypicznym ucieleśnieniem

21 Cz. Miłosz, Liturgia Efraima, „Zeszyty Literackie” 2007, nr 5, numer specjalny: Czesław Miłosz, Historie ludzkie. Pierwodruki (1983-2006), Warszawa-Paryż, s. 22. 
w powszechnym mniemaniu stał się Steve Jobs. Taki geniusz to ktoś podobny do proroka, kto - z wyobraźnią wolną od ekonomicznych kalkulacji - potrafi redukować przypadek, przewidywać konsekwencje swoich wynalazków, wyprzedzać i eliminować problemy związane z ich zastosowaniem - tak, zdawałoby się, nieistotne jak niewłaściwe położenie kciuka na urządzeniu ${ }^{22}$.

\section{Paradoks pierwszy - ontologiczno-psychologiczny}

Oto cztery nierozłączne ontologiczno-psychologiczne aspekty zaprogramowanego świata:

Po pierwsze, rzeczywisty konstrukt. Jedną z dalekosiężnych kulturowych konsekwencji imperatywu wizualizacji jest narastające stopniowo w naszej świadomości przekonanie, że wszystko, co niewymierne, niemierzalne, nie ma dla nas znaczenia i faktycznie nie istnieje - my jako konsumenci bez karty kredytowej lub bankomatowej, czy też jako obywatele bez numeru PESEL lub NIP. Według niektórych - ale to już uwaga z przymrużeniem oka - nie istniejemy, jeśli nie jesteśmy obecni w internecie lub na portalach społecznościowych... Istnieje dziś (dla nas) tylko coś, co daje się zeskanować i cyfrowo zarchiwizować po to, by następnie wywołać/zobrazować to na ekranie i dowolnie zmieniać, według możliwości zastosowanego oprogramowania. To, co postrzegamy jako faktyczne/rzeczywiste, jest teoretycznym konstruktem, zakłada istnienie określonego programu umieszczonego w pamięci operacyjnej komputera.

Wyzwania, jakie stawia zaprogramowana rzeczywistość, mają charakter problemów do rozwiązania - za pomocą nowych, zmienionych lub zaktualizowanych programów. Nie ma już w niej miejsca na tajemnice. Raz na zawsze została odczarowana. Jej zrozumienie - orientowanie się w niej i zapamiętywanie jej - jest przede wszystkim sprawą operacji na obrazach - polega na umiejętności ich kojarzenia i montowania. Oświeceniowy światopogląd zatriumfował. Ziścił się przez to koszmar wizjonerów zachodniej nowoczesności, upatrujących jej nieuchronnego końca, zmierzchu, śmierci i czegokolwiek jeszcze, co miałoby doprowadzić człowieka do zguby, nawet, gdyby miała ona polegać na jego rozpieszczeniu. Co to rozpieszczenie miałoby znaczyć - o tym jeszcze za chwilę.

Po drugie, identyczność jakościowa różnic. W świecie, który utracił swoje dotychczasowe substancjalne znaczenia - nazywam go postmetafizycznym - chodzi o to, żeby wszyscy i wszystko mogło „odróżniać się tak, by nie robiło to różnicy”23. Na tym polega jego „bladość”, o której wspomina Miłosz w przywołanym wyżej cytacie, a która doskonale realizuje się w logice wolnego rynku. Peter Sloterdijk

22 F. Jameson, An American Utopia, w: S. Žižek (red.), An American Utopia: Dual Power and the Universal Army, Verso, London 2016, s. 51, 53.

23 P. Sloterdijk, Pogarda mas. Szkic o walkach kulturowych we współczesnym społeczeństwie, przeł.

B. Baran, Aletheia, Warszawa 2012, s. 142. 
tłumaczy to tak: „Do zadań jednostek [w świecie kapitału - przyp. J.P.H.] należy zdawanie się na coraz liczniejsze oferty towarów, odgrywanie coraz różnorodniejszych ról, coraz bardziej inwazyjne reklamy i coraz bardziej arbitralne sztuczne otoczenia”. Nie ma tu miejsca na nic trwałego - narasta świadomość, ,że stale istnieją możliwości wyboru i boczne wyjścia” - „osoby stają się coraz bledsze, przedmioty coraz barwniejsze”, bezbarwni mają wybierać „pośród różnych postaci barwności. Suwerenem jest ten, kto wybiera kolor sezonu" ${ }^{24}$.

Designerskiej obróbce podlega wszystko - mogą to być równie dobrze bezużyteczne gadżety, niefunkcjonalne meble, jak i zjawiska przemocy, cierpienia, głodu i wojny. Wszystko też traci przez tę obróbkę na wartości, czyli na znaczeniu. $\mathrm{Na}$ poziomie ontologicznym, a co za tym idzie również estetycznym i egzystencjalnym wszystko blaknie, staje się równoważne - może być co najwyżej ,inne”. Tak właśnie kształtują rzeczywistość nowoczesne technologie - one same są produktem pojęciowych budowli, wykazującym - jak pamiętamy - „sztywną regularność rzymskiego kolumbarium" (Nietzsche) z jego matematycznym rygorem i chłodem. To przypadek stylu międzynarodowego i modernizmu - funkcjonalnych, geometrycznych domów, ulokowanych w racjonalnie zorganizowanych i uporządkowanych miastach. Względnie niskie ceny realizacji takich projektów idą w parze ze znacznie wyższymi kosztami, jakie pociągają one w sferze ludzkich wartości, przez swoje znieczulenie na to, co lokalne, bliskie, piękne, ciepłe, swojskie, bezpieczne i niepowtarzalne. Podlegają strukturalistycznej zasadzie medium is the message: maszyny wytwarzające zuniformizowane produkty zostawiają na nich swój ślad - Le Corbusier słusznie mówił dlatego o domach jako maszynach do mieszkania ${ }^{25}$. Funkcjonalne projekty zamieniają różnice w tożsamość, przekonując jednocześnie poprzez design swoich konsumentów-użytkowników, że czynią dokładnie odwrotnie. Na tym polega oszustwo dialektyki oświecenia - $\mathrm{i}$ janusowe oblicze projektowania.

Po trzecie, krucha nieśmiertelność. Estetyczne projektowanie przedmiotów użytkowych ma na celu zwiększenie ich atrakcyjności dla konsumenta. Idealny nabywca jest tak zaprogramowany przez producenta, żeby kierował się żądzą posiadania towaru, która sama siebie pożera ${ }^{26}$. Gdy już coś kupi - samochód, ubranie czy telefon - i zacznie tego używać, błyskawicznie traci do tego zapał i kieruje swoją wyobraźnię ku kolejnym, nowszym, w jego przekonaniu jeszcze lepszym modelom niż ten, który aktualnie posiada. Wiecznie niezaspokojony. Kuszony przez medialne obrazy rzeczy, ich formy narracyjne i techniczną doskonałość. Design podważa w ten sposób zarówno wartość etyki, jak i metafizyki. Usprawiedliwia - moralnie neutralizuje egoizm konsumentów, zniewolonych/uwiedzionych suwerenów, którzy wszystkie-

24 Wszystkie cytaty: P. Sloterdijk, Kryształowy pałac. O filozoficzna teorię globalizacji, przeł. B. Cymbrowski, Wydawnictwo Krytyki Politycznej, Warszawa 2011, s. 260.

25 Zob. A. Flint, Le Corbusier. Architekt jutra, przeł. D. Cieśla-Szymańska, W.A.B., Warszawa 2017; V. Papanek, op. cit., s. 26.

26 R. Sennett, Kultura nowego kapitalizmu, przeł. G. Brzozowski, K. Osłowski, Wydawnictwo Literackie Muza, Warszawa 2010, s. 110. 
mu przypisują tę samą mało- lub nie-ważność i w tym sensie są zawsze sprawiedliwi, by nie powiedzieć: demokratyczni. Wspiera logikę kapitalizmu konsumenckiego, która domaga się coraz większej szybkości, efektywności, coraz większej eliminacji barier na drodze do dokonywania transakcji przez podmioty coraz bardziej wykorzenione, dryfujące, nomadyczne - anonimowe, blade, nijakie. Logikę oszukańczą i chytrą, ponieważ pod pozorem równości - egalitaryzmu i indywidualizmu - rozbija ona zastane hierarchie, instytucje i wartości, promując jednocześnie najsilniejszych, zamieniając ludzi w egoistycznych, konsumenckich drapieżników, ,których jedyną wspólnotą jest uczestnictwo, w miarę możliwości, w rozkoszach rynku”27. W ten oto sposób design zamienia ludzkie doświadczenie - a uwagę tę Zygmunt Bauman odniósł tylko do sztuki współczesnej - w ,nieustanną próbę kruchości nieśmiertelności i odwracalności śmierci" ${ }^{28}$. Strach przed pustką łagodzi jej doraźnymi wypełnieniami - chorobę na śmierć leczy aspiryną. Fenomenologiczny opis zachowań nastawionych na kupowanie, użycie i zużycie rzeczy ukazuje kolejny paradoks designu - wiąże się z pragnieniem czegoś, co stoi już w kolejce do zapomnienia i wyrzucenia na śmietnik. Z przeżywaniem czasu nie jako trwania, lecz jako ciągu krótkotrwałych, ulotnych epizodów, niemających swoich dalszych konsekwencji. Ontologia zdarzeniowa - a do niej jeszcze powrócę - promuje epizodyczność i krótkotrwałość wydarzeń, jest ramą wyjaśniającą, która bardziej niż na refleksję konceptualną, nastawioną na ujmowanie tożsamości rzeczy, stawia na refleksję narracyjną, łączącą opowiadanie z fenomenologicznymi opisami różnic tego, co poszczególne i jednostkowe. Wszystko, co krótkotrwałe i jednorazowe, jest ważniejsze od tego, co trwałe i przeżywa swoich twórców - w sztuce są to dziś głównie happeningi i instalacje, w gospodarce (potencjalnie) wszystkie produkty robione na zamówienie i życzenie klienta.

Po czwarte, przyjemność nieskonsumowana. W konsumenckim postrzeganiu świata dane wrażeniowe są semiotycznie wzmacniane przez atrakcyjność znaku marki firmowej - przez wszystkie skojarzenia i doznania, które marka ze sobą niesie, przez przyjemne poczucie przynależności do wybranej grupy mieszkańców światów przedstawionych w obrazach medialnych. Fenomenologia - jako ogląd i opis tego, co postrzegamy zmysłowo, co dane jest nam przez odczucia i wrażenia, co inaczej mówiąc, jest estetyczne w etymologicznym tego słowa znaczeniu (od gr. aisthesis, oznaczającego percepcję zmysłową) - pokazuje więc, że nie jest ono wolne od tego, co symboliczne, dyskursywne, a więc i społeczne. Sensualność podlega także kulturowym ramom percepcyjnym - entuzjastycznie reagujemy przecież na najmodniejsze kolory i trendy w modzie. Ten entuzjazm jednak szybko w nas wygasa wraz z nieustannym naporem kolejnych obrazów jeszcze piękniejszych rajów medialnych. Pełnia szczęścia stale jest dopiero przed nami - nieosiągalna, oddala się i majaczy tylko na horyzoncie. Pogrążeni w tym namiętnym cugu, zachowujemy się

27 A. Badiou, A. Finkielkraut, Dawni kontestatorzy. O aktualności sporów wokół Maja '68, przeł. W. Dłuski, „Przegląd Polityczny” 2018, nr 148, s. 143.

28 Z. Bauman, Zindywidualizowane społeczeństwo, przeł. O. i W. Kubińscy, Gdańskie Wydawnictwo Psychologiczne, Gdańsk 2008, s. 299. 
nieracjonalnie - wbrew prawom ekonomii i zdrowego rozsądku, przede wszystkim zaś wbrew wspólnemu dla obu tych postaci rozumu prawu sprzeczności, przynajmniej w jego psychologicznym zastosowaniu. W konsumpcyjnym amoku nieustannie musimy się bowiem poruszać i jednocześnie tkwić w miejscu, sycić się chwilą, przebywać w absolutnej teraźniejszości, ciągle mającej dopiero zaistnieć. Celem jest przyjemność, która ma nadejść w stale jeszcze nieistniejącej przyszłości - z chwilą, gdy ta przyszłość stanie się konkretna w teraźniejszości, wraz z nią umyka (przyjemność spala się) i przechodzi w przeszłośćc ${ }^{29}$. Oto psychologiczny paradoks designu.

\section{Paradoks drugi (egzystencjalno-polityczny): kapitalizm, demokracja i egalitarny elitaryzm}

Ontologiczny status świata nowoczesnego wiąże się z dynamiką zmian, która podważa wszelkie stabilne ramy odniesienia dla jego reprezentacji - nie ma w nim trwałych, substancjalnych bytów ani koniecznych relacji między nimi. Adekwatna dla jego wyjaśnienia zdaje się więc wspomniana wcześniej ontologia zdarzeniowa. Ontologia ta zajmuje się rzeczywistością złożoną ze zdarzeń, którym znaczenia nadają media - reprezentacje kulturowe. Rzeczywistość zostaje tu sprowadzona do funkcji umysłu. Stąd i jej wieloznaczność i niestabilność. Swoim mieszkańcom nie daje ona ani poczucia pewności, ani poczucia bezpieczeństwa, o czym donoszą już jej pierwsi budowniczowie, designerzy, miotani owym horror vacui, strachem przed nagłą śmiercią i nadmiernym wysiłkiem, narzekający na to, że

nie ma wygodnego budownictwa; nie ma narzędzi do poruszania i przesuwania rzeczy, co wymaga wiele siły; nie ma wiedzy o powierzchni ziemi ani obliczania czasu, ani sztuki, ani umiejętności, ani sztuki słowa, ani społeczności. A co najgorsze, jest bezustanny strach i niebezpieczeństwo gwałtownej śmierci. I życie człowieka jest samotne, biedne, bez słońca, zwierzęce i krótkie ${ }^{30}$.

Dramat nowoczesnego życia wskazuje na pilną potrzebę środków zaradczych na notoryczny strach i stres, samotność i bezsilność. Ale same te środki nie mogą być też niczym innym jak tylko substytutami i symulacjami, kolejnymi projektami, a właściwie metaprojektami - działają one jak instynkt samozachowawczy, ich funkcja ma bowiem polegać na odciążeniu nas od barier znajdujących się na drodze do realizacji wszelkich naszych projektów, uwolnieniu od oporów ze strony odrażającej i nieogarniętej materii. Poniżej mechanizm ten za Sloterdijkiem opiszę za pomocą metafory rozpieszczania - na tym etapie wystarczy nam świadomość, że cywilizacyjne odciążanie od konieczności, z jakimi musimy zmagać się, walcząc o łatwiejsze i lepsze

29 Zob. Ch. Lloyd, Globalization: Beyond the Ultra-Modernist Narrative to a Critical Realist Perspective on Geopolitics in the Cyber Age, „International Journal of Urban and Regional Research” 2000, vol. 24, nr 2 (June), s. 260-261.

30 T. Hobbes, Lewiatan czyli materia, forma i władza państwa kościelnego i świeckiego, przeł. Cz. Znamierowski, wstęp i przypisy J.C.A. Baskin, Fundacja Aletheia, Warszawa 2005, s. 207. 
życie, niewolne jest od wielorakich implikacji moralnych, społecznych czy politycznych. Była tu już mowa o skutkach, jakie pociągnął za sobą wynalazek samochodu. Zobaczmy teraz, co dzieje się z polityką w związku z komputerem. Pomoże nam w tym krótka obserwacja socjologa Richarda Sennetta:

Oczywiście nikt nie chce zaczynać dnia od przeprogramowania swojego komputera. Jednak nastawienie na łatwość w obsłudze rozkłada demokrację. Demokracja wymaga, aby obywatele chcieli włożyć choć trochę wysiłku w poznanie sposobu działania otaczającego ich świata ${ }^{31}$.

Równość, wielość i różnorodność towarów na rynku oszołamia, olśniewa i hipnotyzuje - wprawia klientów w samozadowolenie, utwierdza w przekonaniu, że świat nie ma już dla nich żadnych granic, a zatem nie ma już też i żadnej inności, różnicy, której nie dałoby się przyswoić. Różnorodność tak oto zamienia się niepostrzeżenie w jednorodność, liberalna otwartość - w totalitarną zamkniętość, demokratyczna wspólnota wartości - w konsumencką publiczność. Ludzie tracą czujność, wolę zabiegania o otwarcie na nowości i różnice, na powiększanie przestrzeni swojego występowania. Demokratyczna promocja idei wolności i równości faktycznie produkuje nierówności, niszczy wszelkie wartości oparte na czymś innym niż towar, wzmacnia jego (towaru) dyktaturę. I w całym tym procesie bierze udział także design - współtworzy uniwersum kapitału i konsumpcji, które wprowadza do świadomości użytkownika prawo do braku szacunku nie tylko do rzeczy ${ }^{32}$, lecz także do ludzi i w ogóle do całego kontekstu społecznego, w którym rzeczy i ludzie się pojawiają - do jego nowoczesnego, politycznego designu związanego z demokracją i obywatelskością. Logika designu katalizuje potencje kapitalizmu do unikalnego łączenia wolności i równości z wyzyskiem i dominacją. Ujawnia - patrz komputer - wewnętrzną sprzeczność uniwersum kapitału i konsumpcji. Uświadamia, że równości formalnej - zakładającej, że wszystkie dobra i prawdy dostępne mają być dla wszystkich - grozi samozniszczenie, jeśli nie wzmocni się jej pewnym momentem zaangażowania. Z nim wiąże się na przykład koncepcja demokracji uczestniczącej lub radykalnej. Temat ten domagałby się rozwinięcia, które wychodziłoby jednak poza ramy tego artykułu. W kontekście demokracji ważne jest dla mnie teraz tylko to, że design bez zwracania uwagi na wyjątkowość jednostki, bez wyzwania - musisz życie swe odmienić! - jest zjawiskiem paradoksalnym: odnosząc się do zróżnicowanych gustów i potrzeb, ma być jednocześnie egalitarny. Ta sprzeczność sprawia, że życie w kapitalizmie zamienia się w nieustanny karnawat - kolejne wynalazki materiałowo-technologiczne jednocześnie wstrząsają kapitalizmem i regenerują go, pozwalają mu reprodukować się przez ciągłe kwestionowanie i rewolucjonizowanie siebie ${ }^{33}$. Intensywność tego procesu niepomiernie wzrasta w fazie kapitalizmu późnego lub postmodernistycznego.

31 R. Sennett, op. cit., s. 135.

32 P. Sloterdijk, Kryształowy pałac..., s. 259.

33 Zob. S. Žižek, Od tragedii do farsy, przeł. M. Kropiwnicki, B. Szelera, Wydawnictwo Krytyki Politycznej, Warszawa 2011, s. 217-219. 


\section{Paradoks trzeci (antropologiczny): nieustanny karnawał i mobilizujące rozpieszczenie}

Wyrażenie „nieustanny karnawał” to oksymoron. Karnawał bowiem, jak wiadomo, wiąże się z cyklicznym podziałem czasoprzestrzeni na to, co osobliwe i fantastyczne, swobodne, kapryśne, zaskakujące, przypadkowe, oraz to, co powszednie, codzienne, przyczynowo powiązane. Nie ma karnawału bez postu - nie można więc żyć w ciągłym karnawale. Ale to tylko analiza semantyczna pojęcia. Kulturowa praktyka jest odporna na logiczne sprzeczności. Tym bardziej, gdy mamy do czynienia z ponowoczesnymi realiami, które wymykają się myśleniu linearnemu, dyskursywnemu, historycznie ukształtowanemu na kulturze pisma/druku, preferują za to myślenie według kolistej logiki hipertekstu, preferowanej w warunkach dominacji obrazu. Ontologię karnawału najlepiej oddać może więc Baudrillardowskie pojęcie hiperrzeczywistości. Oznacza ono iluzję powstałą z nadmiaru wirujących znaków i komunikatów, przesłaniających, znoszących, unieważniających to, co realne. Widzialność, której postępujący wzrost był strategicznym celem nowoczesnej kultury zachodniej, staje się teraz wręcz obsceniczna - wszechobecne obrazy zastępują samą rzeczywistość. Nie istnieje już nic, co byłoby pozaobrazowe. Peter Weibel, artysta i teoretyk sztuki mediów, wyjaśnia to zjawisko następująco:

Epoka postmodernizmu i postmodernistyczna estetyka nie opierają się na ruchomych maszynach, takich jak samochody, koleje żelazne czy samolot, lecz na silnikach komunikacyjnych, tzw. „mediach”, które koncentrują się na tworzeniu, transmisji i przechowywaniu informacji. W świetle globalnie dominującej digitalnej informacji i technologii komunikacyjnej w konsekwencji klasyczne modernistyczne zrównanie maszyn, materiałów i ludzi powinno być zastąpione przez nową digitalną wersję, mianowicie: media, dane i ludzie. Media pojawiają się jako nowa forma rzeczywistości. Podporządkowanie ludzi maszynie - tak jak było ono przedstawione w Dzisiejszych czasach Chaplina - być może zostało zastąpione przez podporządkowanie ludzi mediom i danym, ponieważ oferują one nową rzeczywistość: symulację ${ }^{34}$.

Dla prezentowanej tu argumentacji oznaczałoby to, że przedmioty użytkowe projektowane przy użyciu współczesnych mediów cyfrowych niekoniecznie muszą być więc przyjazne dla demokratycznego ustroju państwa i porządku społecznego. Zamiast emancypować ludzi od maszyn i mobilizować ich do autentycznych działań - musicie życie swe odmienić! - odciągają ich od „prawdziwej” rzeczywistości, ponieważ tworzą nową, alternatywną wobec niej. Alternatywną, czyli bardziej atrakcyjną, a co za tym idzie także i bardziej prawdziwą - w znaczeniu: piękną, użyteczną i przyjemną - od tej, którą wcześniej, w epoce industrialnej, z trudem projektowały i montowały maszyny. I jeszcze jedno, co nadaje dziś designowi znaczenie i atrakcyjność. Otóż tak jak dawniej media - mediację - wiązano z próbą krytycznego myślenia o całości świata społecznego, z pominięciem tego, co w nim inne, fragmen-

34 P. Weibel, Molecular Aesthetics: An Introduction, w: P. Weibel, L. Fruk (red.), Molecular Aesthetics, MIT Press, Cambridge 2013, s. 38. 
taryczne i wykluczone, tak teraz mediacja odnosi się do świata zaprogramowanego przez media elektroniczne, zorganizowanego wokół digitalizacji i komputeryzacji. Elektronicznej mediacji nie da się stotalizować - w postaci, powiedzmy, teorii czy programu - nie chodzi też w niej o to, żeby jej towary były wyprodukowane, lecz o to, żeby - tak jak dane cyfrowe - były one zmanipulowane, jak powiada tym razem amerykański krytyk sztuki Hal Foster. A to znaczy, żeby podlegały automatyzacji, poddawały się projektowaniu i reprojektowaniu, konsumowaniu i rekonsumowaniu. To jedna z przyczyn, dla których znaczenie designu wyolbrzymia się dziś jak nigdy dotąd, tak iż właściwie - jak sugeruje Foster - można by wręcz mówić o „politycznej ekonomii designu" 35 . Ale to kolejny paradoks. Nie byłaby to już bowiem nauka o uniwersalnych (odnoszących się do całości) prawach produkcji, podziału i wymiany środków do zaspokajania ludzkich potrzeb, lecz o niezliczonych sposobach projektowania tych potrzeb, lub inaczej: ich symulowania w odniesieniu do poszczególnych jednostek. Życie podporządkowane logice mediów i danych faktycznie może dlatego każdemu z nas z osobna przypominać nieustanny karnawat.

Symulacja oznacza pozorowanie czegoś, co nie istnieje, lub inaczej: jest sposobem tworzenia za pomocą modeli - projektów - rzeczywistości, która nie istnieje poza tymi modelami lub projektami ${ }^{36}$. Jako taka doskonale wpisuje się w kulturę konsumentów nastawionych na nieskończoną przemianę materii. W kulturze tej bowiem obowiązuje zasada przewartościowania wszystkich wartości - mechanizm rozpoznany u początków kultury masowej właśnie jako nihilizm ${ }^{37}$. Otwartość na towary pozbawia nas nie tylko szacunku do nich, ale także i gotowości do postaw altruistycznych, do wyrzeczeń, rezygnacji z własnych przyjemności na rzecz realizacji norm moralnych i dobra wspólnego, w rezultacie zwalnia nas więc ona także od powinności doskonalenia się, osiągania mistrzostwa w jakimś rzemiośle, dyscyplinie czy umiejętności. Kupowany towar ma być przyjazny użytkownikowi - i tyle. Nie może - nie powinien - konsumenta sobą absorbować, zmuszać do jakiegoś/ jakiegokolwiek wysiłku związanego, powiedzmy, z opanowaniem obsługi nowego komputera, samochodu czy telefonu. Możliwa dzięki nowym technologiom łatwość i szybkość dostępu i użycia - tak „na kliknięcie” - rozpieszcza go więc, uwalnia od konieczności zaangażowania. Rozpieszczenie to termin antropologii historycznej, który wskazuje na to, że cywilizacja w ogóle, w szczególności zaś cywilizacja dobrobytu, nadmiaru towarów, niesie z sobą psychologiczne odciążenie, obniżenie poziomu stresu, czyli poczucia konieczności; daje efekt cieplarnianej egzystencji coraz większe pole wolności i egzystencjalnych szans ${ }^{38}$.

Rzeczywistość, a przynajmniej to, co za rzeczywiste uznajemy, w wyniku działania mechanizmów konsumenckich i rozpieszczających przestaje być jakością zastaną i nabiera elastyczności w procesie jej tworzenia. Mechanizm jej kreacji można

\footnotetext{
35 H. Foster, The ABC of Contemporary Design, „October” 2002, nr 100 (Spring), s. 195. 
przedstawić następująco: Z chwilą wymiany pieniądza na towar realna staje się możliwa przyszłość - natomiast wszystko, czego nie daje się sprzedać, zostaje zwrócone i staje się rzeczywistością odrzuconą. Moment, w którym rozstajemy się z naszymi pieniędzmi, jest chwilą, kiedy zapewniamy sobie stworzenie małego, na naszą miarę, fragmentu rzeczywistości - nie tylko fizycznej czy kulturowej, lecz także psychologicznej, etycznej i behawioralnej ${ }^{39}$. Zlewamy się z nim - staje się on przedłużeniem naszych zmysłów. Tak oto zasada rzeczywistości, która wedle tradycyjnej psychoanalitycznej interpretacji miała blokować naszą zmysłowość i domagać się od nas unikania przykrości, na powrót może zamienić się w zasadę rozkoszy dzięki cywilizacyjnemu rozpieszczaniu za pomocą coraz bardziej wyszukanego technologicznie projektowania.

\section{Paradoks czwarty (estetyczny): sztuka i nihilistyczne piękno konsumpcji}

Pierwotnie, gdy mówimy o designie, mamy na myśli estetyczne projektowanie rzeczy użytkowych, upiększanie tego, co funkcjonalne. Czasem taki efekt pojawia się w sposób niezamierzony. Bywa bowiem i tak, że dzięki temu, iż wiemy, do czego dane przedmioty służą, jaką mają pełnić funkcję, jawią się nam one jako piękne w znaczeniu: doskonale użyteczne, służące temu, do czego zostały stworzone. Temat to nienowy i przy jego okazji również po raz kolejny możemy wrócić do klasyków filozofii zachodniej. Otóż wątek piękna jako odpowiedniości przewija się w estetyce od czasów Sokratesa, który odróżniał dwa rodzaje piękna: jedno, rozpoznane przez pitagorejczyków, polega na pięknie samej rzeczy, jej doskonałej struktury, proporcji jej części, drugie - na pięknie proporcji doskonale dostosowanej do swojego przeznaczenia ${ }^{40}$. Niektóre $\mathrm{z}$ nieestetycznych właściwości percepcyjnych przedmiotów użytkowych z epoki industrialnej - na przykład maszyn, narzędzi czy budynków o charakterze przemysłowym - mogą dlatego wyróżniać się jako doskonale funkcjonalne i nadawać im szczególny rodzaj estetycznego wyglądu. Faktura cegły lub betonu czy barwa rdzy pokrywającej metal opuszczonych fabryk lub magazynów mogą dawać doskonałe efekty estetyczne - przemawiać autentycznym wyglądem, surowością lub prostotą; tworzyć unikalne przestrzenie dla loftowych aranżacji. Stare dźwigi czy żurawie mogą być tak zaprojektowane, że wielkie masy żelaza zdają się lekkie, jakby unosiły się w powietrzu ${ }^{41}$.

Design uwikłany jest nie tylko w paradoks piękna jako odpowiedniości. W XX wieku bierze on udział $\mathrm{w}$ - charakterystycznym dla tej epoki - projekcie kulturowym, opartym na sprzeczności między pięknem prowokacji artystycznej a nihili-

\footnotetext{
39 A. Dunne, F. Raby, Speculative Everything: Design, Fiction, and Social Dreaming, MIT Press, Cambridge, MA 2013, s. 37.

40 Zob. W. Tatarkiewicz, Dzieje sześciu pojęć, PWN, Warszawa 1988, s. 153.

41 Zob. G. Parsons, A. Carlson, Functional Beauty, Clarendon Press, Oxford 2008, s. 99-100.
} 
stycznym pięknem konsumpcji ${ }^{42}$. I tak na przykład prowokacje popartu od początku były związane z przemysłowo produkowanymi przedmiotami, komercyjną grafiką i technikami drukarskimi lat 50. XX wieku. Ten związek okazał się obopólnie korzystny: popartyści swoimi pracami inspirowali designerów do tworzenia nowych przedmiotów, zwłaszcza w obszarze przemysłu modowego czy meblarskiego. Meble z lat 60. i 70. - jeden z najbardziej rozpoznawalnych to Marilyn Sofa, wykonana w 1972 roku we Włoszech - robione były z plastiku w estetyce popartowskiej. Jasne kolory, mocne geometryczne kształty, zmysłowe, ironiczne, symboliczne - zwrócone przeciw tradycyjnym sposobom ich projektowania i produkowania. Plastik był już wtedy symbolem konsumeryzmu. Nie był nowością. Choć nie występował w programach nauczania designu przemysłowego w szkole Bauhausu, szybko pojawił się u jej kontynuatorów już w latach 30 . Na kursach designu prowadzonych wtedy w londyńskiej Central School of Arts and Crafts zwracano uwagę na „plastik, elektryczne urządzenia oświetleniowe oraz artykuły codziennego użytku"43 - produkowano w rezultacie plastikowe wieszaki, klamki do drzwi i inne akcesoria. Ale to dopiero popart uczynił z plastiku swój znak firmowy. Do dziś wizualny kod popartu znajdujemy w projektowaniu opakowań, elementów dekoracyjnych czy też w fotografii naśladującej polaroidy Warhola ${ }^{44}$.

Współistnienie sprzecznych jakości i tendencji - samoistnych wartości sztuki i wartości rynkowych designu - nie wiąże się tylko z popartem. Design w fotografii stał się schroniskiem także dla studium martwej natury, której - tradycyjnie - znaczenie polega na ukazywaniu przedmiotów codziennego użytku w ich niezwykłym za każdym razem układzie, wytrącaniu nas przez to z rutynowej percepcji otoczenia, wyrywaniu w bezczasowość samych rzeczy. A to już inny rodzaj nieśmiertelności niż ten, który jest doświadczeniem opisanych powyżej pieszczochów. Do niego wielekroć odwoływała się sztuka awangardowa - fotografie, fotomontaże i plakaty konstruktywistów radzieckich, kolaże surrealistów, dzieła dadaistów, ready mades powstawały przy udziale przypadku w procesie twórczym, miały odsłaniać pewne archaiczne stany rzeczy przez umieszczanie przedmiotów użytkowych w nowych, niespotykanych dotąd kontekstach. A wszystko to po to, by pozwolić odbiorcom na ponowne ich odkrywanie, oddawanie się impulsom nieświadomości, wchodzenie w świat snu, fantazji, podobnych do tych wywoływanych przez narkotyki lub choroby umysłowe ${ }^{45}$. Artysta nie chce być twórcą sztuki, którą można kupić i sprzedać, chce być natomiast - tak jak Aleksandr Rodczenko - konstruktorem, inżynierem, technikiem: język malarstwa za pomocą zmiany technologicznej, jaka dokonuje się

42, „[...] pierwsza połowa XX wieku, a najdalej lata sześćdziesiąte tego stulecia (potem będzie to trudniejsze), były teatrem dramatycznej walki pomiędzy pięknem prowokacji a pięknem konsumpcji" (U. Eco, Historia piękna, przeł. A. Kuciak, Rebis, Poznań 2005, s. 414).

43 Cyt. za: A. Powers, op. cit., s. 155.

44 Zob. J. Arsen, A Short Guide through the History of Pop Art and Design, https://www.widewalls.ch/ pop-art-design/ (dostęp: 3.05.2019).

45 U. Eco, op. cit., s. 415-417. 
w fotografii (lekki aparat z kliszą z filmem małoobrazkowym), przekierowuje w stronę języka inżynierii społecznej. Sfotografowany fakt, jak mówi artysta, ma „nie tylko konkurować z malarstwem, ale pokazywać każdemu nowy doskonały sposób wyjaśniania zjawiska w nauce, technice i życiu współczesnego człowieka"46.

Tak czy inaczej celem sztuki awangardowej nie było pozbawianie rzeczy wartości, ale przeciwnie - przywracanie jej im. Awangardowa sztuka wizualna zwraca się ku przedmiotom mieszczańskiej konsumpcji. Destrukcja tradycyjnego malarstwa polega na zakwestionowaniu tego, że należy ono tylko do sfery przedstawiania - stąd technologiczna rewolucja, polegająca, na przykład w kolażach Picassa czy Maxa Ernsta, na budowaniu/kształtowaniu/montowaniu obrazu z fragmentów przedmiotów z codzienności: fajki, gitary, tanich tapet, mebli, znalezionych obrazków, sznurków, desek itp. Na pytanie, dlaczego więc i ta sztuka zamieniła się ostatecznie w towar rynkowy, dlaczego i ona podzieliła losy designu i stała się produktem nabywanym przez ludzi chętnie na co dzień uczestniczących w kulturze masowej - noszących modne ciuchy, kierujących się kanonami mody promowanymi przez telewizję i kino - przeciw której buntuje się awangarda, Umberto Eco odpowie tylko tyle, że ta sprzeczność jest typowa dla XX wieku ${ }^{47}$. Jest to ta sama sprzeczność, którą sztuka awangardowa podziela wraz z designem $\mathrm{w}$ świecie kapitału.

\section{My współcześni designerzy nieparadoksalni?}

Czy zatem design może uwolnić się od semantycznych i pragmatycznych paradoksów i sprzeczności, skazujących nas na przewlekły stres i rozczarowanie, zamieniających nasze osiągnięcia w porażki, z których wydobywamy się tylko po to, by powtórzyć ten sam scenariusz wydarzeń? Ale może tak sformułowany problem to także nic innego jak tylko takie samo projektowanie - projekt badań, polegający na próbie przechytrzenia współczesnego języka i metodologii nauk społecznych. Postawienia na ich gruncie - post-, a właściwie antymetafizycznym, czyli najogólniej związanym z empiryzmem i pozytywizmem - metafizycznego w rzeczy samej pytania o to, czy można poradzić sobie w życiu bez oszukiwania „natury”? Krótko mówiąc, skoro nie ma już „natury”, to nie ma też powodu do jej oszukiwania, deformującego formowania, do wikłania się w sprzeczności między naszymi hubrystycznymi intencjami panowania nad naturą a szacunkiem dla jej niezmiennych właściwości? Skoro nie ma już „natury”, to wszystko wolno?

We współczesnym dyskursie o designie jego wewnętrzna sprzeczność została zdemaskowana - a mówiąc dokładniej: zdekonstruowana - jako paralogizmy, czyli błędne rozumowania, oparte na fałszywym - metafizycznym właśnie - pojmowaniu

46 Cyt. za: A. Mazur, Ikony Europy: Aleksander Rodczenko „Dziewczyna z Leica”, „Digital Camera”, 29.11.2014, https://digitalcamerapolska.pl/inspiracje/1537-ikony-europy-aleksander-rodczenko-dziewczyna-z-leica (dostęp: 22.06.2019).

47 U. Eco, op. cit., s. 418. 
„natury”, a co za tym idzie także i samych projektowanych „rzeczy”. Dekonstrukcja ta przebiega w dwóch etapach. Pierwszy wiąże się z zerwaniem z tradycją estetyczną. Nie chodzi już dziś bowiem w designie, jako teorii i praktyce kulturowej, o samą zmianę wyglądów rzeczy i związaną z tym radość życia, lecz (bardziej) o zmianę naszych sposobów myślenia i postaw, które kształtują nas samych i otaczający nas świat. Projektowanie ma być rodzajem spekulacji na temat tego, jak świat i my w nim moglibyśmy wyglądać. Drugi etap dekonstrukcji wiąże się z uświadomieniem sobie, że działania i decyzje designerów zawsze mają konsekwencje publiczne i powinny być dlatego także przedmiotem publicznego decydowania - negocjowania, dyskutowania, konsultowania z różnymi aktorami społecznymi, potencjalnymi użytkownikami projektowanych przedmiotów ${ }^{48}$. Przedmioty te w rezultacie są „rzeczami publicznymi”, czyli „rzeczami” w etymologicznym tego słowa znaczeniu ${ }^{49}$. Łacińskie „res” to rzecz, przedmiot, sprawa, władza, a także „miejsce zgromadzeń”, rzecz publiczna - res publica. Takie „rzeczy” gromadzą dlatego wokół siebie ludzi, jednoczą ich i dzielą między sobą. Należy je więc pojmować w perspektywie normatywnej: powinny mianowicie pomagać nam kształtować nasze życie i nas samych, stanowić ogniska, wokół których gromadzimy się po to, by dyskutować na temat swoich spraw i oceniać je (dane rzeczy) pod względem znaczenia, jakie one dla nas mają. Stąd biorą się moralne i polityczne znaczenia designu ${ }^{50}$. Zamiast rozpieszczać, ma nas aktywizować, zamiast odciążać - uwrażliwiać i stresować nas, służyć nam jako narzędzie krytyki społecznej.

W rezultacie designerzy to dziś krytyczni konstruktywiści, świadomi tego, że ich projekty nie są żadnymi bytami autonomicznymi, ponieważ swoje znaczenie czerpią z opisów, opowieści i interpretacji w kategoriach społecznych. Nie są to krytycy w stylu frankfurckim, bardziej niż interesy kapitalistów związane z utrzymaniem politycznego status quo interesuje ich bowiem krytyka jako sceptycyzm, nieufność wobec wszelkich oczywistości. I w tym sensie każdy dobry design jest według nich krytyczny. W swojej pracy korzystają z metod i podejść artystycznych, pomagających użytkownikom projektowanych rzeczy uświadomić sobie sprawczą, performatywną moc tworzenia przez nie alternatywnych sposobów życia, alternatywnych wobec zastanych stanów rzeczy, z ich niedoskonałościami, które zwykliśmy traktować jako „normalne”. Designerska krytyka ma pomóc im/nam w wychodzeniu ze stanu rozpieszczenia i stawaniu się coraz bardziej wnikliwymi, troskliwymi i świadomymi konsekwencji swoich działań obywatelami-konsumentami ${ }^{51}$.

48 Zob. A. Dunne, F. Raby, op. cit., s. 160. Na temat technologii jako konstruktu społecznego zob. S. Fritsch, Technology and Global Affairs, „International Studies Perspectives” 2011, vol. 12, s. $27-45$. Na takie znaczenie „rzeczy” zwraca uwagę Bruno Latour. Zob. idem, From Realpolitik to Dingpolitik: or How to Make Things Public, w: B. Latour, P. Weibel (red.), Making Things Public: Atmospheres of Democracy, MIT Press, Cambridge 2005, s. 4-31.

50 P.-P. Verbeek, Design Ethics and the Morality of Technological Artifacts, w: P.E. Vermaas et al. (red.), Philosophy and Design..., s. 102.

51 A. Dunne, F. Raby, op. cit., s. 37. 
Design jest więc ostatecznie tworzony przez nas samych - i wzajemnie on wytwarza nas. Jego teorię krytyczną wpisuje się dziś w konstruktywistyczne studia techniczne, w których przyjmuje się, że technologie są społecznie konstruowane nie tylko z uwagi na interesy czy plany poszczególnych aktorów społecznych, lecz także na ich szersze kulturowe tło. Bez tego tła nie zrozumiemy chociażby różnicy między znaczeniem roweru w Chinach i w Polsce ${ }^{52}$. Ale to nie wszystko. Wiąże się z tym coś znacznie ważniejszego. Skoro to, co rozumiemy przez naturę, jest także konstruktem kulturowym, to świadome tego faktu współczesne projektowanie samo musi ograniczać swoje tendencje do przechytrzania i oszukiwania jej. W świecie postmetafizycznym nie wszystko zatem jest dozwolone. Jeśli projektanci są świadomi współkreowania „natury”, to nie mogą zamykać rzeczy w epizodycznych i krótkotrwałych zastosowaniach, lecz muszą roztaczać przed nimi pewną perspektywę na trwanie - na jakąś transcendencję autotelicznych wartości. Taką wartością nadrzędną jest samo życie. Jest ono dziś produktem nauki - genetyki, nanotechnologii, syntetycznej biologii (projektującej sztuczne systemy biologiczne wzorowane na naturalnych), które podważają nasze dotychczasowe rozumienie natury i sugerują nowe możliwości jej projektowania, poczynając od mikroorganizmów, przez rośliny, zwierzęta, a kończąc na człowieku i jego środowisku. Zapłodnienia pozaustrojowe in vitro, klonowanie zwierząt i genetyczne ich modyfikowanie w celu poprawienia ich potencjału żywnościowego, produkowanie mięsa z komórek zwierzęcych w laboratoriach itp. Zdolność do projektowania życia to główny cel tego rodzaju zjawisk - mają one ogromne znaczenie dla tego, co to znaczy człowiek, jak wzajemnie się do siebie odnosimy, dla naszej tożsamości, lęków i nadziei - jak twierdzą sami designerzy ${ }^{53}$.

\section{Wnioski}

Historia designu pokrywa się z historią nowoczesności datowaną umownie od rewolucji przemysłowej. Jest to historia narastającego w nas przekonania, że w otaczającym nas świecie nie ma nic trwałego, niepowtarzalnego, oryginalnego i że wszystko może być inaczej niż jest, że istnieją nieskończone możliwości wyborów i przekształceń zastanych kształtów rzeczy i ludzi. Coraz mniej szanujemy wobec tego rzeczy, ponieważ coraz mniej one nas kosztują - coraz łatwiej je zdobywamy, wytwarzamy i przekształcamy. Rozpieszczają nas. Odwdzięczamy się im za to tym, że niszczymy je i produkujemy z nich odpady. Jeśli pojęcie designu zawiera w sobie paradoks, wewnętrzną sprzeczność, to wolno przypuszczać, że może on zadziałać też inaczej, przywrócić szacunek do nich, a nawet i zachwyt dla nich, nauczyć troski o nie i o świat wokół nich.

52 Zob. P. Feng, A. Feenberg, op. cit., s. 112.

53 A. Dunne, F. Raby, op. cit., s. 48. 
Po z górą stu latach opowieści o designie nie chodzi już w nim tylko o widzialne, zewnętrzne kształty rzeczy ani o większą radość życia, jaką miałyby nam one sprawiać, ani o zasypywanie przepaści między sztuką a konsumpcją, lecz o nas samych, o to, kim jesteśmy i jak żyjemy jako ludzie. W świecie zagrożonym przez ekologiczne kataklizmy, epidemie, zanieczyszczenia powietrza, wód i gleb, klęski żywiołowe wywołane bezpośrednio lub pośrednio przez działalność ludzką projektować to już nie to samo, co eksperymentować z naturą, deformować ją przez formowanie, nie licząc się ze skutkami takich przedsięwzięć. Ale to już także nie to samo, co czynić w tych warunkach nasze życie bardziej znośnym ani łagodzić nasz strach przed śmiercią i samotnością. Projektować to teraz tyle, co tworzyć życie od nowa. Możliwie wolne od dotychczasowych niedoskonałości - przy założeniu, że możliwości ich poprawiania lub doskonalenia nie są nieograniczone, że wolność wyborów i przekształceń nie jest absolutna. Imperatyw wizualizowania zostaje zastąpiony imperatywem moralnym: pamiętaj, abyś wszystkiego, co projektujesz, nigdy nie używał tylko jako środka do lepszego, przyjemniejszego życia, lecz zarazem także jako celu, czegoś, co jest integralnym komponentem tego życia, co go do niego powołuje i w nim podtrzymuje.

\section{Bibliografia}

Arsen J., A Short Guide through the History of Pop Art and Design, https://www.widewalls. ch/pop-art-design/ (dostęp: 3.05.2019).

Arystoteles, Retoryka, w: idem, Retoryka. Poetyka, przeł. H. Podbielski, PWN, Warszawa 1988.

Badiou A., Finkielkraut A., Dawni kontestatorzy. O aktualności sporów wokót Maja '68, przeł. W. Dłuski, „Przegląd Polityczny” 2018, nr 148.

Barańczak S., Wstęp, w: Antologia angielskiej poezji metafizycznej XVII stulecia, wybór, przekł., wstęp i oprac. S. Barańczak, PIW, Warszawa 1982.

Baudrillard J., Symulakry i symulacja, przeł. S. Królak, Wydawnictwo Sic!, Warszawa 2005.

Bauman Z., Zindywidualizowane społeczeństwo, przeł. O. i W. Kubińscy, Gdańskie Wydawnictwo Psychologiczne, Gdańsk 2008.

Biblia Tysiaclecia, Pallottinum, https://biblia.deon.pl/rozdzial.php?id=279 (dostęp: 10.09.2019).

DIA Nothing Need Be Ugly Chapter 1 - Official Support and Initial Successes, http://www. dia.org.uk/page/aboutus/nothing_Need_be_Ugly/DIA_Nothing_Need_be_Ugly_Chapter_1_-_Official_Support_and_Initial_Successes (dostęp: 5.06.2019).

Dunne A., Raby F., Speculative Everything: Design, Fiction, and Social Dreaming, MIT Press, Cambridge, MA 2013.

Eco U., Historia piękna, przeł. A. Kuciak, Rebis, Poznań 2005.

Feng P., Feenberg A., Thinking about Design: Critical Theory of Technology and the Design Process, w: P.E. Vermaas et al. (red.), Philosophy and Design: From Engineering to Architecture, Springer, Austin 2008. 
Flint A., Le Corbusier. Architekt jutra, przeł. D. Cieśla-Szymańska, W.A.B., Warszawa 2017. Flusser V., O terminie ,, design”, przeł. P. Wiatr, „Kultura Współczesna” 2016, nr 4.

Foster H., The ABC of Contemporary Design, „October” 2002, nr 100 (Spring).

Fritsch S., Technology and Global Affairs, „International Studies Perspectives” 2011, vol. 12.

Hobbes T., Lewiatan czyli materia, forma i władza państwa kościelnego i świeckiego, przeł.

Cz. Znamierowski, wstęp i przypisy J.C.A. Baskin, Fundacja Aletheia, Warszawa 2005.

Jameson F., An American Utopia, w: S. Žižek (red.), An American Utopia: Dual Power and the Universal Army, Verso, London 2016.

Kołakowski L., Odwet sacrum w kulturze świeckiej, w: idem, Czy diabet może być zbawiony i 27 innych kazań, Aneks, Londyn 1984.

Latour B., From Realpolitik to Dingpolitik: or How to Make Things Public, w: B. Latour, P. Weibel (red.), Making Things Public: Atmospheres of Democracy, MIT Press, Cambridge 2005.

Lloyd Ch., Globalization: Beyond the Ultra-Modernist Narrative to a Critical Realist Perspective on Geopolitics in the Cyber Age, „International Journal of Urban and Regional Research" 2000, vol. 24, nr 2 (June).

Manovich L., Czym jest wizualizacja?, przeł. M. Korzewski, w: M. Boguni-Borowska, P. Sztompka (red.), Fotospoleczeństwo. Antologia tekstów z socjologii wizualnej, Znak, Kraków 2012.

Manovich L., Język nowych mediów, przeł. P. Cypryański, Wydawnictwa Akademickie i Profesjonalne, Warszawa 2006.

Mazur A., Ikony Europy: Aleksander Rodczenko „Dziewczyna z Leica”, „Digital Camera”, 29.11.2014, https://digitalcamerapolska.pl/inspiracje/1537-ikony-europy-aleksander-rodczenko-dziewczyna-z-leica (dostęp: 22.06.2019).

Miłosz Cz., Liturgia Efraima, „Zeszyty Literackie” 2007, nr 5, numer specjalny: Cz. Miłosz, Historie ludzkie. Pierwodruki (1983-2006), Warszawa-Paryż.

Nietzsche F., O prawdzie $i$ kłamstwie $w$ pozamoralnym sensie, w: idem, Pisma pozostałe 1862-1875, przeł. B. Baran, Inter Esse, Kraków 1993.

Papanek V., Dizajn dla realnego świata. Środowisko człowieka i zmiana społeczna, przeł. J. Holzman, Recto Verso, Łódź 2012.

Parsons G., Carlson A., Functional Beauty, Clarendon Press, Oxford 2008.

Platon, Państwo, t. II, przeł. W. Witwicki, PWN, Warszawa 1991.

Powers A., Bauhaus Goes West: Modern Art and Design in Britain and America, Thames \& Hudson Ltd., London 2019.

Saler M.T., The Avant-Garde in Interwar England: Medieval Modernism and the London Underground, Oxford University Press, Oxford 1999.

Sennett R., Kultura nowego kapitalizmu, przeł. G. Brzozowski, K. Osłowski, Wydawnictwo Literackie Muza, Warszawa 2010.

Sloterdijk P., Kryształowy pałac. O filozoficzna teorię globalizacji, przeł. B. Cymbrowski, Wydawnictwo Krytyki Politycznej, Warszawa 2011.

Sloterdijk P., Pogarda mas. Szkic o walkach kulturowych we współczesnym społeczeństwie, przeł. B. Baran, Aletheia, Warszawa 2012.

Tatarkiewicz W., Dzieje sześciu pojęć, PWN, Warszawa 1988. 
Jan P. Hudzik

Verbeek P.-P, Design Ethics and the Morality of Technological Artifacts, w: P.E. Vermaas et al. (red.), Philosophy and Design: From Engineering to Architecture, Springer, Austin 2008.

Weibel P., Molecular Aesthetics: An Introduction, w: P. Weibel, L. Fruk (red.), Molecular Aesthetics, MIT Press, Cambridge 2013.

Žižek S., Od tragedii do farsy, przeł. M. Kropiwnicki, B. Szelera, Wydawnictwo Krytyki Politycznej, Warszawa 2011. 